\title{
Pelagibacterium halotolerans gen. nov., sp. nov. and Pelagibacterium luteolum sp. nov., novel members of the family Hyphomicrobiaceae
}

Correspondence

Xue-Wei Xu

xuxw@sio.org.cn

\author{
Xue-Wei Xu, ${ }^{1,2}$ Ying-Yi Huo, ${ }^{3}$ Chun-Sheng Wang, ${ }^{1,2}$ Aharon Oren, ${ }^{4}$ \\ Heng-Lin Cui, ${ }^{5}$ Eve Vedler ${ }^{6}$ and $\mathrm{Min} \mathrm{Wu}^{3}$
}

${ }^{1}$ Laboratory of Marine Ecosystem and Biogeochemistry, State Oceanic Administration, Hangzhou 310012, People's Republic of China

${ }^{2}$ Second Institute of Oceanography, State Oceanic Administration, Hangzhou 310012, People's Republic of China

${ }^{3}$ College of Life Sciences, Zhejiang University, Hangzhou 310058, People's Republic of China

${ }^{4}$ Institute of Life Sciences, and the Moshe Shilo Minerva Center for Marine Biogeochemistry, The Hebrew University of Jerusalem, Jerusalem 91904, Israel

${ }^{5}$ School of Food \& Biological Engineering, Jiangsu University, Zhenjiang 212013, People's Republic of China

${ }^{6}$ Institute of Molecular and Cell Biology, Tartu University, Tartu 51010, Estonia

Two Gram-negative, motile, aerobic bacterial strains, designated B2 ${ }^{\top}$ and 1_C16_27 ${ }^{\top}$, were respectively isolated from a seawater sample collected from the East China Sea and a semi-coke sample from north-eastern Estonia. Their genetic, phenotypic and chemotaxonomic properties were studied. The isolates were short rods with polar flagella and were positive for catalase and oxidase activities. Q-10 was the predominant respiratory ubiquinone. The major polar lipids were phosphatidylglycerol, diphosphatidylglycerol and two unidentified glycolipids. The major fatty acids were nonadecanoic $\left(\mathrm{C}_{19: 0}\right.$ cyclo), octadecanoic $\left(\mathrm{C}_{18: 0}\right.$ and $\left.\mathrm{C}_{18: 0} 3-\mathrm{OH}\right)$, octadecenoic $\left(\mathrm{C}_{18: 1}\right)$ and hexadecanoic $\left(\mathrm{C}_{16: 0}\right)$ acids. The $\mathrm{G}+\mathrm{C}$ content of the genomic DNA was 58.1-59.3 mol\%. 16S rRNA gene sequence analysis revealed that the two isolates represent a distinct lineage within the family Hyphomicrobiaceae. The phylogenetically closest relatives were Cucumibacter (92.7-93.7 \% 16S rRNA gene sequence similarity), Devosia (92.9-94.4\%) and Zhangella (91.7-92.1\%). Differential phenotypic properties, together with phylogenetic and genetic distinctiveness, revealed that strains $B 2^{\top}$ and 1_C16_27 $7^{\top}$ could be differentiated from each other and from members of the genera Cucumibacter, Devosia and Zhangella. Therefore, it is proposed that strains $B 2^{\top}$ and 1_C16_27 $7^{\top}$ represent two novel species in a new genus, for which the names Pelagibacterium halotolerans gen. nov., sp. nov. (the type species; type strain $\mathrm{B}^{\top}{ }^{\top}=\mathrm{CGMCC} 1.7692^{\top}=\mathrm{JCM} 15775^{\top}$ ) and Pelagibacterium luteolum sp. nov. (type strain 1_C16_27 $7^{\top}=$ CGMCC $1.10267^{\top}=$ JCM $16552^{\top}=$ CELMS EEUT 1 C $1627^{\top}$ ) are proposed.
The family Hyphomicrobiaceae, class Alphaproteobacteria, comprises a morphologically and metabolically heterogeneous group of micro-organisms (Garrity et al., 2005). The establishment of the family Hyphomicrobiaceae was based mainly on phylogenetic relationships of $16 \mathrm{~S}$ rRNA gene sequences (Garrity et al., 2005; Lee et al., 2005). At the time

The GenBank/EMBL/DDBJ accession numbers for the 16S rRNA gene sequences of strains B2 ${ }^{\top}$ and 1_C16_27 ${ }^{\top}$ are EU709017 and EF540455, respectively.

Four supplementary figures and a supplementary table are available with the online version of this paper. of writing, the family encompassed 18 genera: Ancalomicrobium, Angulomicrobium, Aquabacter, Blastochloris, Cucumibacter, Devosia, Dichotomicrobium, Filomicrobium, Gemmiger, Hyphomicrobium, Maritalea, Methylorhabdus, Pedomicrobium, Prosthecomicrobium, Rhodomicrobium, Rhodoplanes, Seliberia and Zhangella (Euzéby, 1997).

Most species within the family Hyphomicrobiaceae have been isolated from various non-marine habitats (freshwater, soil, plant roots, sewage, swamps, activated sludge, chicken, saline pond and lake sediment, etc.). Only a few have been isolated from offshore seawater: Cucumibacter marinus, Filomicrobium fusiforme, Hyphomicrobium aestuarii and 
Zhangella mobilis (Gliesche et al., 2005; Schlesner, 2005; Hwang \& Cho, 2008; Xu et al., 2009). In this paper, we present a polyphasic study describing two novel chemoheterotrophic bacteria, isolated from a seawater sample off the Chinese coast and a semi-coke sample from Estonia, which belong to this family.

A sample was collected from the East China Sea $\left(30^{\circ} 58^{\prime}\right.$ $16^{\prime \prime} \mathrm{N} 125^{\circ} 59^{\prime} 24^{\prime \prime} \mathrm{E}$ ) from a depth of $70 \mathrm{~m}$ (temperature $16.7{ }^{\circ} \mathrm{C}$; salinity $33.95 \%$ ). Approximately $100 \mu \mathrm{l}$ seawater was plated on marine agar 2216 (MA). After 3 days of aerobic incubation at $30{ }^{\circ} \mathrm{C}$, one light-yellowish colony, designated $\mathrm{B} 2^{\mathrm{T}}$, was picked. Strain 1_C16_27 $7^{\mathrm{T}}$ was isolated from a sample collected from an oil shale chemical industry solid waste (semi-coke) depository area in north-eastern Estonia ( $59^{\circ} 23^{\prime} 44^{\prime \prime} \mathrm{N} 27^{\circ} 13^{\prime} 05^{\prime \prime} \mathrm{E}$ ) in October 2003. Ten subsamples of semi-coke from a depth of 5-15 cm were taken with a soil corer and then mixed to form a composite sample. Microbial cells were suspended from the soil sample into sterile $0.9 \% \mathrm{NaCl}$ solution by vortexing. After setting of the soil particles, $100 \mu \mathrm{l}$ of the clear supernatant was plated onto minimal medium agar plates (M9 salts supplemented with trace elements) with hexadecane as the sole carbon and energy source (a piece of filter paper, soaked with hexadecane, was placed inside the cover lid of the agar plate) (Truu et al., 2003). After a week of aerobic incubation at $22{ }^{\circ} \mathrm{C}$, one yellowish colony, designated 1_C16_27 $7^{\mathrm{T}}$, was picked. The two strains were purified by repeated restreaking; purity was confirmed by the uniformity of cell morphology. Unless otherwise stated, strains $\mathrm{B}^{\mathrm{T}}$ and $1 \_\mathrm{C} 16 \_27^{\mathrm{T}}$ were maintained in yeast extract broth (YEB; basal medium supplemented with $5 \mathrm{~g}$ yeast extract and $8.3 \mathrm{~g} \mathrm{NaCl} \mathrm{l}^{-1}$ ) (Mikhailov et al., 2006). The basal medium (BM) contained (per 1 distilled water) $1.0 \mathrm{~g}$ $\mathrm{NH}_{4} \mathrm{Cl}, 0.044 \mathrm{~g} \mathrm{~K}_{2} \mathrm{HPO}_{4}, 0.028 \mathrm{~g} \mathrm{FeSO}$. $7 \mathrm{H}_{2} \mathrm{O}, 500 \mathrm{ml}$ artificial seawater and $50 \mathrm{ml}$ Tris/ $\mathrm{HCl}(1 \mathrm{M}, \mathrm{pH}$ 7.5). The artificial seawater contained (per l distilled water) $23.4 \mathrm{~g}$ $\mathrm{NaCl}, 24.6 \mathrm{~g} \mathrm{MgSO}_{4} .7 \mathrm{H}_{2} \mathrm{O}, 1.5 \mathrm{~g} \mathrm{KCl}$ and $2.9 \mathrm{~g} \mathrm{CaCl}_{2}$.

Optimal conditions for growth were determined in PYM and YEB medium with 0, 1.5, 3.0, 4.0, 5.0, 6.0, 8.0, 10.0, 12.0, 13.0, 14.0 and $15.0 \%(\mathrm{w} / \mathrm{v}) \mathrm{NaCl}$ (Nakagawa et al., 1996). The PYM medium contained (per l distilled water) $10.0 \mathrm{~g}$ peptone $(\mathrm{BD}), 2.0 \mathrm{~g}$ yeast extract $(\mathrm{BD})$ and $1.0 \mathrm{~g}$ $\mathrm{MgSO}_{4} \cdot 7 \mathrm{H}_{2} \mathrm{O}, \mathrm{pH}$ 7.0. The $\mathrm{pH}$ range for growth was determined by adding MES ( $\mathrm{pH}$ 5.0-6.0), PIPES ( $\mathrm{pH}$ 6.57.0), Tricine ( $\mathrm{pH} 7.5-8.5)$ or CAPSO ( $\mathrm{pH} 9.0-10.0)$ to YEB medium at a concentration of $40 \mathrm{mM}$. The temperature range for growth was determined by incubating at 4 , $10,15,20,25,30,35,40,42,45$ and $48{ }^{\circ} \mathrm{C}$. Cell motility and morphology were examined by optical microscopy (BX40; Olympus). The presence of flagella was confirmed by transmission electron microscopy (JEM-1230; JEOL).

Oxidase activity was determined by oxidation of $1 \% p$ aminodimethylaniline oxalate. Catalase activity was determined by bubble production in $3 \%(\mathrm{v} / \mathrm{v}) \mathrm{H}_{2} \mathrm{O}_{2}$ solution (Dong \& Cai, 2001). Single carbon source assimilation tests were performed by using BM medium supplemented with
$1.5 \%(\mathrm{w} / \mathrm{v}) \mathrm{NaCl}$. The corresponding filter-sterilized sugar $(0.2 \%)$, alcohol $(0.2 \%)$, organic acid $(0.1 \%)$ or amino acid $(0.1 \%)$ was added to liquid medium. Acid production was tested by using modified MOF medium supplemented with $1 \%$ sugars or alcohols (Leifson, 1963; Xu et al., 2008). Nitrate reduction, gluconate oxidation, lecithinase and urease activities and the ability to hydrolyse aesculin, casein, DNA, gelatin and Tweens 40,60 and 80 were determined according to Dong \& Cai (2001). Susceptibility to antibiotics was detected on marine 2216 agar (MA; BD) or PYM agar plates using antibiotic discs containing the following amounts ( $\mu \mathrm{g}$ unless otherwise stated): amoxicillin (10), ampicillin (10), bacitracin (0.04 IU), cefotaxime (30), cefoxitin (30), chloramphenicol (30), erythromycin (15), kanamycin (30), neomycin (30), nitrofurantoin (300), novobiocin (30), nystatin (100), penicillin (10), polymyxin (300 IU), rifampicin (5), streptomycin (10), tetracycline (30) and tobramycin (10). Additional enzyme activities and biochemical characteristics were determined by using API 20 $\mathrm{NE}$ and API ZYM kits at $30{ }^{\circ} \mathrm{C}$ as recommended by the manufacturer (bioMérieux).

Isoprenoid quinones were analysed as described previously (Komagata \& Suzuki, 1987) by reversed-phase HPLC. Fatty acid methyl esters obtained from cells grown on MA at $30{ }^{\circ} \mathrm{C}$ were analysed according to the instructions of the Microbial Identification System (MIDI; Microbial ID). Polar lipids were extracted using a chloroform/methanol system and separated by two-dimensional TLC using silica gel $60 \mathrm{~F}_{254}$ aluminium-backed thin-layer plates (Merck) (Kates, 1986). The solvent systems chloroform/methanol/ water $(65: 24: 4$, by vol.) and chloroform/glacial acetic $\mathrm{acid} / \mathrm{methanol} /$ water $(80: 12: 15: 4$, by vol.) were used in the first and second dimensions. Separated components were visualized by treating the plates with $10 \%(\mathrm{w} / \mathrm{v})$ molybdatophosphoric acid followed by heating at $150{ }^{\circ} \mathrm{C}$ for 5 min. Genomic DNA was obtained using the method described by Marmur (1961). The purified DNA was hydrolysed with P1 nuclease and the nucleotides were dephosphorylated with calf intestine alkaline phosphatase (Mesbah \& Whitman, 1989). The G+C content of the resulting deoxyribonucleosides was determined by reversed-phase HPLC and calculated from the ratio of deoxyguanosine $(\mathrm{dG})$ and thymidine $(\mathrm{dT})$ (Mesbah \& Whitman, 1989).

The 16S rRNA gene was amplified and analysed as described previously (Xu et al., 2007). Sequence data were aligned with CLUSTAL W 1.8 (Thompson et al., 1994). The sequence was compared with closely related sequences of reference organisms from the EzTaxon service (Chun et al., 2007). Phylogenetic trees were constructed by the neighbourjoining (Saitou \& Nei, 1987) and maximum-parsimony (Fitch, 1971) methods with the MEGA 4 program package (Tamura et al., 2007) and the maximum-likelihood method (Felsenstein, 1981) with the TreePuzzle 5.2 program. Evolutionary distances were calculated according to the algorithm of Kimura's two-parameter model (Kimura, 1980) for the neighbour-joining method. 
The two isolates were Gram-negative, rod-shaped, motile, oxidase-positive and possessed Q-10 as the predominant quinone. Cell division occurred by binary fission. Electron micrographs of negative stained cells did not reveal prosthecae (Supplementary Fig. S1, available in IJSEM Online). Other physiological and chemotaxonomic characteristics of strains $\mathrm{B} 2^{\mathrm{T}}$ and $1 \_C 16 \_27^{\mathrm{T}}$ are summarized in the species descriptions. Phenotypic characteristics that serve to differentiate the two strains from their closest phylogenetic relatives are listed in Table 1.

$16 \mathrm{~S}$ rRNA gene sequence comparisons to representative bacteria with validly published names indicated that strains $\mathrm{B} 2^{\mathrm{T}}$ and 1_C16_27 ${ }^{\mathrm{T}}$ were affiliated with the family Hyphomicrobiaceae. Based on analysis by the EzTaxon service, the two strains were related most closely to type strains of the genera Cucumibacter (92.7-93.7\% similarity), Devosia (92.9-94.4\%) and Zhangella (91.7-92.1\%) as well as Prosthecomicrobium pneumaticum (93.1-93.2\%), and they showed $<90 \%$ sequence similarity to other described species of the Hyphomicrobiaceae. Phylogenetic trees constructed with all three treeing methods indicated that the two strains clustered with the genera Cucumibacter and Zhangella (Fig. 1 and Supplementary Figs S2 and S3). Within this cluster, strain $\mathrm{B}^{\mathrm{T}}$ was found to be closely related to strain 1_C16_27 $7^{\mathrm{T}}$, as supported by a high bootstrap resampling value ( $99 \%$ by the neighbour-joining method) (Fig. 1). Therefore, the relatively low sequence similarities between strains $\mathrm{B}^{\mathrm{T}}$ and $1 \_\mathrm{C} 162^{\mathrm{T}} 7^{\mathrm{T}}$ and their phylogenetic neighbours indicate strongly that these two strains are members of a new genus in the family Hyphomicrobiaceae.

The dominant fatty acid for strains $\mathrm{B} 2^{\mathrm{T}}$ and $1 \_\mathrm{C} 16 \_27^{\mathrm{T}}$ was $\mathrm{C}_{18: 1} \omega 7 c$, characteristic of the vast majority of species within the Alphaproteobacteria. The relative amounts of $\mathrm{C}_{19: 0}$ cyclo $\omega 8 c$, 11-methyl $\mathrm{C}_{18: 1} \omega 7 c$ and $\mathrm{C}_{18: 1}$ varied according to the age of the culture (Supplementary Table S1). The respective contents of $\mathrm{C}_{18: 1} \omega 7 c$ of strains $\mathrm{B}^{\mathrm{T}}$ and 1_C16_27 $7^{\mathrm{T}}$ decreased from 61.3 and $75.3 \%$ after 1 day to 58.0 and $74.6 \%$ after 2 days and 12.1 and $59.0 \%$ after 3 days. The proportions of $\mathrm{C}_{19: 0}$ cyclo $\omega 8 \mathrm{c}$ and 11-methyl $\mathrm{C}_{18: 1} \omega 7 c$ increased accordingly. Together, $\mathrm{C}_{19: 0}$ cyclo $\omega 8 c$, 11-methyl $C_{18: 1} \omega 7 c$ and $C_{18: 1}$ made up $67-83 \%$ of the total fatty acids of strains $\mathrm{B} 2^{\mathrm{T}}$ and $1 \_C 16 \_27^{\mathrm{T}}$. In general, the percentages of unsaturated fatty acids of strains $\mathrm{B} 2^{\mathrm{T}}$ $(68.2-75.3 \%)$ and 1_C16_27 $7^{\mathrm{T}}(68.2-80.4 \%)$ were close to that of Zhangella mobilis CGMCC $1.7002^{\mathrm{T}}(71.8-83.5 \%)$ and were greater than those of Cucumibacter marinus DSM $18995^{\mathrm{T}}$, Devosia riboflavina DSM $7230^{\mathrm{T}}$ and Devosia geojensis DSM 19414 ${ }^{\mathrm{T}}$ (42.0-62.5\%). 10-Methyl $\mathrm{C}_{19: 0}$ was detected in extracts of strains $\mathrm{B} 2^{\mathrm{T}}$ and 1_C16_27 $7^{\mathrm{T}}$ but not in the four reference strains; iso- $\mathrm{C}_{19: 0}$ was detected extracts from 2- and 3-day cultures of C. marinus DSM $18995^{\mathrm{T}}$ and $Z$. mobilis CGMCC $1.7002^{\mathrm{T}}$ but was absent in strains $\mathrm{B} 2^{\mathrm{T}}$ and 1 C $16-27^{\mathrm{T}}$.

The results of two-dimensional TLC analysis of polar lipids extracted from strains $\mathrm{B} 2^{\mathrm{T}}$ and $1 \_\mathrm{C} 16 \_27^{\mathrm{T}}$ as well as three
Table 1. Taxonomic characteristics that differentiate strains $B 2^{\top}$ and 1_C16_27 ${ }^{\top}$ from related members of the family Hyphomicrobiaceae

Strains: 1, B2 ${ }^{\mathrm{T}}$; 2, 1_C16_27 ${ }^{\mathrm{T}}$; 3, Cucumibacter marinus DSM $18995^{\mathrm{T}}$; 4, Zhangella mobilis CGMCC $1.7002^{\mathrm{T}}$; 5 , Devosia riboflavina DSM $7230^{\mathrm{T}} ; 6$, Devosia geojensis DSM $19414^{\mathrm{T}}$. Unless stated otherwise, data were obtained from this study under identical growth conditions. To determine substrate utilization for growth, all strains except $C$. marinus DSM $18995^{\mathrm{T}}$ were grown in BM broth; C. marinus DSM $18995^{\mathrm{T}}$ was grown on BM agar plates because its growth in BM broth was very slow. To determine susceptibility to antibiotics, all strains except $D$. riboflavina DSM $7230^{\mathrm{T}}$ were grown on MA (BD) plates; $D$. riboflavina DSM $7230^{\mathrm{T}}$ was grown on PYM agar plates because its growth on MA was very slow. +, Positive; -, negative; w, weakly positive; NA, no data available.

\begin{tabular}{|c|c|c|c|c|c|c|}
\hline Characteristic & 1 & 2 & 3 & 4 & 5 & 6 \\
\hline Colony colour ${ }^{*}$ & LY & $\mathrm{Y}$ & C & PY & $\mathrm{C}$ & WH \\
\hline $\begin{array}{l}\text { Growth at } 10 \% \mathrm{NaCl} \\
(\mathrm{w} / \mathrm{v})\end{array}$ & + & - & $+{ }^{a_{\dagger}}$ & $-{ }^{b}$ & - & NA \\
\hline Nitrate reduction & - & - & - & + & - & - \\
\hline Urease & + & + & - & - & + & + \\
\hline \multicolumn{7}{|l|}{ Hydrolysis of: } \\
\hline Casein & + & + & - & - & - & - \\
\hline DNA & - & - & - & - & - & + \\
\hline \multicolumn{7}{|l|}{ Acid production from: } \\
\hline Ethanol & + & + & NA & - & - & - \\
\hline Glycerol & + & + & NA & - & + & + \\
\hline Raffinose & - & - & NA & - & + & + \\
\hline Rhamnose & + & - & NA & - & + & + \\
\hline \multicolumn{7}{|l|}{ Utilization of: } \\
\hline Gluconate & + & + & - & - & - & - \\
\hline Lactose & - & + & - & - & + & + \\
\hline Mannitol & + & + & - & - & + & + \\
\hline L-Ornithine & + & - & + & + & - & - \\
\hline Salicin & + & - & + & + & + & + \\
\hline Sorbitol & - & + & - & - & + & + \\
\hline Succinate & + & + & - & + & + & - \\
\hline \multicolumn{7}{|l|}{ Sensitivity to: } \\
\hline Bacitracin (0.04 IU) & + & + & - & + & - & - \\
\hline Kanamycin $(30 \mu \mathrm{g})$ & - & + & + & $+{ }^{b}$ & - & - \\
\hline Neomycin $(30 \mu \mathrm{g})$ & + & + & + & + & + & - \\
\hline Novobiocin $(30 \mu \mathrm{g})$ & + & + & + & + & + & - \\
\hline \multicolumn{7}{|l|}{ API ZYM results } \\
\hline Alkaline phosphatase & + & - & + & + & + & + \\
\hline$\alpha$-Chymotrypsin & - & - & $\mathrm{W}$ & $\mathrm{W}$ & $\mathrm{w}$ & - \\
\hline Cystine arylamidase & - & - & + & + & $\mathrm{w}$ & - \\
\hline$\beta$-Galactosidase & - & - & + & + & + & + \\
\hline$\alpha$-Glucosidase & + & - & + & + & - & $\mathrm{w}$ \\
\hline Trypsin & + & - & + & + & + & - \\
\hline $\begin{array}{l}\text { DNA G }+ \text { C content } \\
(\mathrm{mol} \%)\end{array}$ & 59.3 & 58.1 & $62.9^{a}$ & $53.1^{b}$ & $61.4^{c}$ & $60.8^{d}$ \\
\hline
\end{tabular}

${ }^{*} \mathrm{C}$, Cream; LY, light yellow; PY, pale yellow; wH, white; $\mathrm{Y}$, yellow. $\dagger$ Data from: $a$, Hwang \& Cho (2008); $b$, Xu et al. (2009); c, Nakagawa et al. (1996); d, Ryu et al. (2008). 


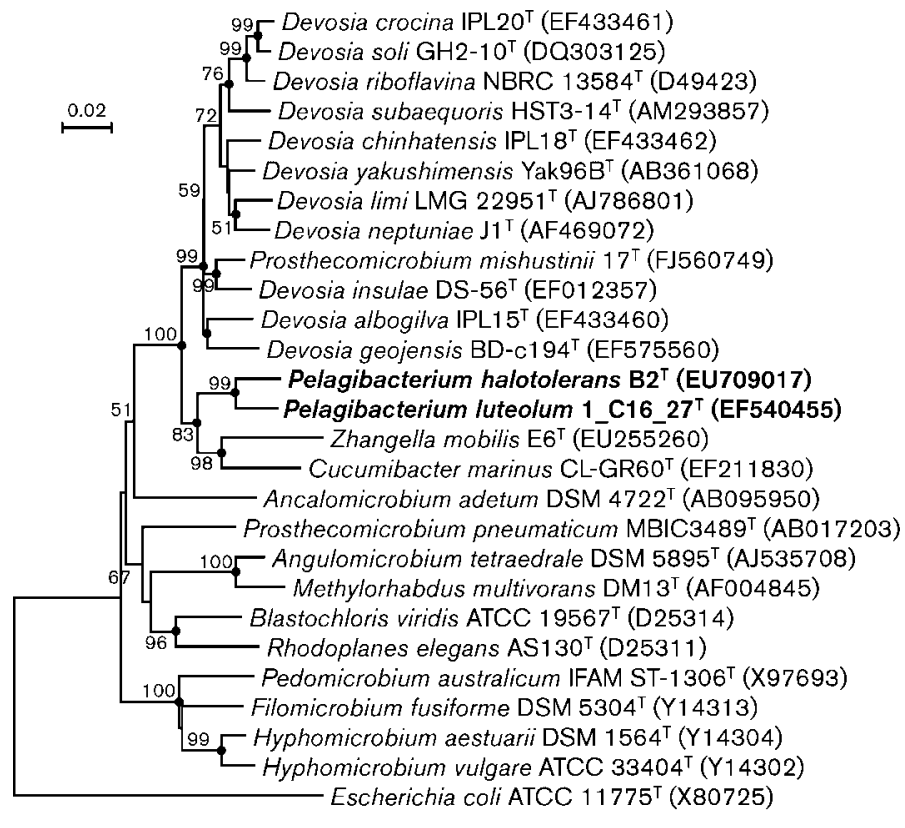

Fig. 1. Neighbour-joining tree based on $16 \mathrm{~S}$ rRNA gene sequences, showing the phylogenetic relationships of the novel isolates and related members of the Hyphomicrobiaceae. Bootstrap values are based on 1000 replicates; values $>50 \%$ are shown. Filled circles indicate nodes recovered in both maximum-likelihood and maximum-parsimony trees. Bar, 0.02 substitutions per nucleotide position. reference strains, C. marinus DSM $18995^{\mathrm{T}}$, D. geojensis DSM $19414^{\mathrm{T}}$ and Z. mobilis CGMCC $1.7002^{\mathrm{T}}$, are shown in Supplementary Fig. S4. The polar lipid profiles of all five strains were dominated by phosphatidylglycerol, diphosphatidylglycerol and two unidentified glycolipids (GL1 and GL3). Strains B2 ${ }^{\mathrm{T}}$ and $1 \_\mathrm{C} 16 \_27^{\mathrm{T}}$ did not contain relatively large amounts of unknown lipid L16, in marked contrast to the phylogenetically related genera Cucumibacter and Zhangella. Seven polar lipids (L1, L2, L3, L5, L6, L8 and L11) were detected in both strains $B 2^{\mathrm{T}}$ and $1{ }_{-} \mathrm{C} 16 \_27^{\mathrm{T}}$ in minor amounts. Four of them (L2, L3, L6 and L8) were also found in the three reference strains, but L5 and L11 are characteristic lipids of strains $\mathrm{B} 2^{\mathrm{T}}$ and $1{ }_{-} \mathrm{C} 16 \_27^{\mathrm{T}}$. In addition, L15, found in the three reference strains, was not detected in strains $\mathrm{B} 2^{\mathrm{T}}$ and 1_C16_27 ${ }^{\mathrm{T}}$. 10-Methyl $\mathrm{C}_{19: 0}$ was found in both strains $\mathrm{B}^{\mathrm{T}}{ }^{-}(0.6-0.9 \%)$ and $1 \_\mathrm{C} 16 \_27^{\mathrm{T}}$ $(0.3-0.4 \%)$, but not in related organisms (Supplementary Table S1). In addition to these differences, some phenotypic characteristics of strain $\mathrm{B} 2^{\mathrm{T}}$ and $1 \_\mathrm{C} 16 \_27^{\mathrm{T}}$, e.g. $\beta$ galactosidase, hydrolysis of casein and utilization of gluconate, distinguish the two novel isolates from the previously described species C. marinus, Z. mobilis, D. riboflavina and D. geojensis (Table 1). Therefore, chemotaxonomic and physiological features suggest that strains $\mathrm{B} 2^{\mathrm{T}}$ and 1_C16_27 $7^{\mathrm{T}}$ represent a novel genus of the family Hyphomicrobiaceae. The main respiratory quinone of strains B2 ${ }^{\mathrm{T}}$ and 1_C16_27 ${ }^{\mathrm{T}}$ was Q-10 (94.2 and $96.2 \%$, respectively), while Q-9 was a minor component (5.8 and $3.8 \%$, respectively).

Strains $\mathrm{B} 2^{\mathrm{T}}$ and $1 \_\mathrm{C} 16 \_27^{\mathrm{T}}$ could be differentiated from each other by their fatty acid compositions and a number of phenotypic characteristics (Table 1) and on the basis of their $16 \mathrm{~S}$ rRNA gene sequences. The total content of $\mathrm{C}_{19: 0}$ cyclo $\omega 8 c$, 11-methyl $\mathrm{C}_{18: 1} \omega 7 c$ and $\mathrm{C}_{18: 1}$ of strain $\mathrm{B}^{\mathrm{T}}$
$(66.8-73.3 \%)$ was lower than that of strain 1_C16_27 (78.1-79.0\%) grown under the same conditions. The two strains could also be distinguished by their different abilities to produce acid from rhamnose, their $\mathrm{NaCl}$ range for growth, utilization of lactose, L-ornithine, salicin and sorbitol, susceptibility to kanamycin and enzyme activities such as alkaline phosphatase, $\alpha$-glucosidase and trypsin (Table 1). The 16S rRNA gene sequence divergence between strain $\mathrm{B} 2^{\mathrm{T}}$ and 1_C16_2 $27^{\mathrm{T}}$ was $3.4 \%$, which exceeded the commonly accepted threshold of $3 \%$ for the distinction of different genomic species (Stackebrandt \& Goebel, 1994). On the basis of the physiological and chemotaxonomic characteristics presented and 16S rRNA gene sequence comparisons, it is proposed that strains $\mathrm{B} 2^{\mathrm{T}}$ and $1 \_\mathrm{C} 16 \_27^{\mathrm{T}}$ represent two novel species in a new genus, for which the names Pelagibacterium halotolerans gen. nov., sp. nov. and Pelagibacterium luteolum sp. nov. are proposed.

\section{Description of Pelagibacterium gen. nov.}

Pelagibacterium (Pe.la' gi.bac.te'ri.um. L. n. pelagus the sea; N.L. n. bacterium from Gr. n. bakterion a small rod; N.L. neut. n. Pelagibacterium a rod isolated from the sea).

Gram-negative, non-spore-forming bacteria. Divide by binary division. Motile. Catalase- and oxidase-positive. Aerobic chemoheterotrophs. Major polar lipids are phosphatidylglycerol, diphosphatidylglycerol and two unidentified glycolipids. Small amounts of seven unidentified lipids (L1, L2, L3, L5, L6, L8 and L11) are detected. Major fatty acids include nonadecanoic $\left(\mathrm{C}_{19: 0}\right.$ cyclo), octadecanoic $\left(\mathrm{C}_{18: 0}\right.$ and $\left.\mathrm{C}_{18: 0} 3-\mathrm{OH}\right)$, octadecenoic $\left(\mathrm{C}_{18: 1}\right)$ and hexadecanoic $\left(\mathrm{C}_{16: 0}\right)$ acids. The main respiratory quinone is Q-10, with Q-9 as a minor component. The $\mathrm{G}+\mathrm{C}$ content of the genomic DNA is $58.1-59.3 \mathrm{~mol} \%$. Belongs to the class Alphaproteobacteria. Analysis of 16S rRNA gene 
sequences showed that Pelagibacterium species are most closely related to the members of the genera Cucumibacter, Devosia and Zhangella. The type species is Pelagibacterium halotolerans.

\section{Description of Pelagibacterium halotolerans sp. nov.}

Pelagibacterium halotolerans (ha.lo.to'le.rans. Gr. n. hals, halos salt; L. part. adj. tolerans tolerating; N.L. part. adj. halotolerans salt-tolerating, referring to the organism's ability to tolerate high salt concentrations).

Cells are $0.4-0.6 \mu \mathrm{m}$ wide and $2-3 \mu \mathrm{m}$ long. Motile by means of several polar flagella. Young cultures consist of slightly curved rods. Colonies are 1-2 $\mathrm{mm}$ in diameter, circular, smooth, elevated, semi-transparent and light yellowish after 3 days at $30{ }^{\circ} \mathrm{C}$. Growth occurs at 0 $13.0 \%(\mathrm{w} / \mathrm{v}) \mathrm{NaCl}$, with optimum growth at $3.0-4.0 \%$ $(\mathrm{w} / \mathrm{v})$. Grows at $\mathrm{pH} 6.0-9.5$ and $10-42{ }^{\circ} \mathrm{C}$ (optimum growth at $\mathrm{pH} 7.0$ and $30{ }^{\circ} \mathrm{C}$ ). Nitrate is not reduced. Aesculin and casein are hydrolysed. Gelatin, DNA, starch and Tweens 40, 60 and 80 are not hydrolysed. Gluconate oxidation, glucose fermentation, $\beta$-galactosidase and urease activities are positive. Negative for arginine dihydrolase, indole production and lecithinase. The following substrates are utilized for growth: acetate, L-alanine, L-arabinose, L-asparagine, L-aspartate, cellobiose, citrate, ethanol, Dgalactose, gluconate, glucose, glycerol, L-glutamine, myoinositol, lactate, malate, maltose, mannitol, D-mannose, L-ornithine, pyruvate, ribose, rhamnose, salicin, L-serine, succinate, sucrose, trehalose and D-xylose. The following compounds are not utilized as sole carbon sources: Larginine, L-cysteine, glycine, formate, fumarate, L-histidine, isoleucine, lactose, L-lysine, malonate, L-methionine, propionate, raffinose, sorbitol and sorbose. Acid is produced from L-arabinose, ethanol, D-galactose, glucose, glycerol, inositol, maltose, mannitol, D-mannose, ribose, rhamnose, salicin, sucrose, trehalose and D-xylose. Susceptible to ( $\mu \mathrm{g}$ per disc unless otherwise stated) amoxicillin (10), ampicillin (10), bacitracin (0.04 IU), cefotaxime (30), cefoxitin (30), chloramphenicol (30), erythromycin (15), neomycin (30), nitrofurantoin (300), novobiocin (30), penicillin (10), rifampicin (5) and tetracycline (30), but not to kanamycin (30), nystatin (100), polymyxin (300 IU), streptomycin (10) or tobramycin (10). In the API ZYM system, acid and alkaline phosphatases, $N$-acetyl- $\beta$-glucosaminidase, esterase (C4), esterase lipase (C8), $\alpha$ - and $\beta$-glucosidases, leucine arylamidase (weak reaction), naphthol-AS-BI-phosphohydrolase and trypsin activities are present, whereas $\alpha$ chymotrypsin, cystine arylamidase, $\alpha$-fucosidase, $\alpha$ - and $\beta$-galactosidases, $\beta$-glucuronidase, lipase (C14), $\alpha$-mannosidase and valine arylamidase activities are absent. In addition to the major polar lipids described for the genus, contains a third unidentified glycolipid. Trace amounts of nine unidentified lipids are detected. The major fatty acids are $\mathrm{C}_{19: 0}$ cyclo $\omega 8 c, 11$-methyl $\mathrm{C}_{18: 1} \omega 7 c, \mathrm{C}_{18: 1} \omega 7 c, \mathrm{C}_{16: 0}$ and
$\mathrm{C}_{18: 0}$. The DNA $\mathrm{G}+\mathrm{C}$ content of the type strain is $59.3 \mathrm{~mol} \%$ (HPLC).

The type strain, $\mathrm{B} 2^{\mathrm{T}}\left(=\mathrm{CGMCC} 1.7692^{\mathrm{T}}=\mathrm{JCM} 15775^{\mathrm{T}}\right)$, was isolated from a seawater sample collected from the East China Sea.

\section{Description of Pelagibacterium luteolum sp. nov.}

Pelagibacterium luteolum (lu.te.o'lum. L. neut. adj. luteolum yellowish).

Cells are 0.5-0.9 $\mu \mathrm{m}$ wide and 1.5-2.5 $\mu \mathrm{m}$ long. Short rodshaped. Motile by means of a single polar flagellum. Colonies are 1-2 $\mathrm{mm}$ in diameter, circular, smooth, elevated, semi-transparent and yellowish after 3 days at $30{ }^{\circ} \mathrm{C}$. Growth occurs at $0-5.0 \%(\mathrm{w} / \mathrm{v}) \mathrm{NaCl}$, with optimum growth at $0.5 \%(\mathrm{w} / \mathrm{v})$. Grows at $\mathrm{pH} 6.0-9.5$ and $4-37{ }^{\circ} \mathrm{C}$ (optimum growth at $\mathrm{pH} 7.5$ and $30{ }^{\circ} \mathrm{C}$ ). Nitrate is not reduced. Aesculin and casein are hydrolysed. Gelatin, DNA, starch and Tweens 40,60 and 80 are not hydrolysed. Gluconate oxidation, glucose fermentation, $\beta$ galactosidase and urease activities are positive. Negative for arginine dihydrolase and indole production. The following substrates are utilized for growth: acetate, L-alanine, cellobiose, citrate, ethanol, D-galactose, gluconate, glucose, glycerol, L-glutamine, myo-inositol, lactate, lactose, maltose, mannitol, D-mannose, pyruvate, rhamnose, L-serine, sorbitol, succinate, sucrose, trehalose and D-xylose. The following compounds are not utilized as sole carbon sources: L-cysteine, glycine, formate, L-histidine, isoleucine, L-lysine, malonate, L-ornithine, propionate and raffinose. Assimilation of fumarate and salicin is weakly positive. Acid is produced from L-arabinose, ethanol, D-galactose, glucose, glycerol, inositol, maltose, mannitol, D-mannose, rhamnose, sorbitol, sucrose, trehalose and D-xylose. Susceptible to ( $\mu \mathrm{g}$ per disc unless otherwise stated) amoxicillin (10), ampicillin (10), bacitracin (0.04 IU), cefotaxime (30), cefoxitin (30), chloramphenicol (30), erythromycin (15), kanamycin (30), neomycin (30), nitrofurantoin (300), novobiocin (30), penicillin (10), rifampicin (5) and tetracycline (30), but not to nystatin (100), polymyxin (300 IU), streptomycin (10) or tobramycin (10). In the API ZYM system, acid phosphatase, $N$ acetyl- $\beta$-glucosaminidase, esterase (C4), esterase lipase (C8), $\beta$-glucosidase, leucine arylamidase (weak reaction) and naphthol-AS-BI-phosphohydrolase activities are present, whereas alkaline phosphatase, $\alpha$-chymotrypsin, cystine arylamidase, $\alpha$-fucosidase, $\alpha$ - and $\beta$-galactosidase, $\alpha$-glucosidase, $\beta$-glucuronidase, lipase (C14), $\alpha$-mannosidase, trypsin and valine arylamidase activities are absent. Trace amounts of ten unidentified lipids are detected. The major fatty acids are $\mathrm{C}_{18: 1} \omega 7 c, \mathrm{C}_{19: 0}$ cyclo $\omega 8 c, \mathrm{C}_{18: 0}$ and 11-methyl $\mathrm{C}_{18: 1} \omega 7 c$. The DNA G $+\mathrm{C}$ content of the type strain is $58.1 \mathrm{~mol} \%$ (HPLC).

The type strain, 1_C16_27 $7^{\mathrm{T}}\left(=\mathrm{CGMCC} 1.10267^{\mathrm{T}}=\mathrm{JCM}\right.$ $16552^{\mathrm{T}}=$ CELMS EEUT $\left.1 \mathrm{C} 1627^{\mathrm{T}}\right)$, was isolated from a semi-coke sample collected from north-eastern Estonia. 


\section{Acknowledgements}

This work was supported by grants from the Ministry of Science and Technology of China 863 Program (2007AA021305), the National Natural Science Foundation of China (40806066), the Zhejiang Provincial Natural Science Foundation of China (Y5080060) and the Chinese Offshore Investigation and Assessment (908-ZC-I-02).

\section{References}

Chun, J., Lee, J.-H., Jung, Y., Kim, M., Kim, S., Kim, B. K. \& Lim, Y.-W. (2007). EzTaxon: a web-based tool for the identification of prokaryotes based on $16 \mathrm{~S}$ ribosomal RNA gene sequences. Int J Syst Evol Microbiol 57, 2259-2261.

Dong, X.-Z. \& Cai, M.-Y. (2001). Determinative Manual for Routine Bacteriology. Beijing: Scientific Press.

Euzéby, J. P. (1997). List of Bacterial Names with Standing in Nomenclature: a folder available on the Internet. Int J Syst Bacteriol 47, 590-592. http://www.bacterio.cict.fr

Felsenstein, J. (1981). Evolutionary trees from DNA sequences: a maximum likelihood approach. J Mol Evol 17, 368-376.

Fitch, W. M. (1971). Toward defining the course of evolution: minimum change for a specific tree topology. Syst Zool 20, 406-416.

Garrity, G. M., Bell, J. A. \& Lilburn, T. (2005). Family VIII. Hyphomicrobiaceae Babudieri 1950, 589. In Bergey's Manual of Systematic Bacteriology, 2nd edn, vol. 2C, p. 476. Edited by D. J. Brenner, N. R. Krieg, J. T. Staley \& G. M. Garrity. New York: Springer.

Gliesche, C., Fesefeldt, A. \& Hirsch, P. (2005). Genus I. Hyphomicrobium Stutzer and Hartleb 1898, $76^{\mathrm{AL}}$. In Bergey's Manual of Systematic Bacteriology, 2nd edn, vol. 2C, pp. 476-494. Edited by D. J. Brenner, N. R. Krieg, J. T. Staley \& G. M. Garrity. New York: Springer.

Hwang, C. Y. \& Cho, B. C. (2008). Cucumibacter marinus gen. nov., sp. nov., a marine bacterium in the family Hyphomicrobiaceae. Int $J$ Syst Evol Microbiol 58, 1591-1597.

Kates, M. (1986). Techniques of Lipidology, 2nd edn. Amsterdam: Elsevier.

Kimura, M. (1980). A simple method for estimating evolutionary rates of base substitutions through comparative studies of nucleotide sequences. J Mol Evol 16, 111-120.

Komagata, K. \& Suzuki, K. (1987). Lipid and cell-wall analysis in bacterial systematics. Methods Microbiol 19, 161-207.

Lee, K.-B., Liu, C.-T., Anzai, Y., Kim, H., Aono, T. \& Oyaizu, H. (2005). The hierarchical system of the 'Alphaproteobacteria': description of Hyphomonadaceae fam. nov., Xanthobacteraceae fam. nov. and Erythrobacteraceae fam. nov. Int J Syst Evol Microbiol 55, 1907-1919.

Leifson, E. (1963). Determination of carbohydrate metabolism of marine bacteria. J Bacteriol 85, 1183-1184.

Marmur, J. (1961). A procedure for the isolation of deoxyribonucleic acid from microorganisms. J Mol Biol 3, 208-218.
Mesbah, M. \& Whitman, W. B. (1989). Measurement of deoxyguanosine/thymidine ratios in complex mixtures by high-performance liquid chromatography for determination of the mole percentage guanine + cytosine of DNA. J Chromatogr A 479, 297-306.

Mikhailov, V. V., Romanenko, L. A. \& Ivanova, E. P. (2006). The genus Alteromonas and related proteobacteria. In The Prokaryotes: a Handbook on the Biology of Bacteria, 3rd edn, vol. 6, pp. 597-645. Edited by M. Dworkin, S. Falkow, E. Rosenberg, K. H. Schleifer \& E. Stackebrandt. New York: Springer.

Nakagawa, Y., Sakane, T. \& Yokota, A. (1996). Transfer of "Pseudomonas riboflavina" (Foster 1944), a gram-negative, motile rod with long-chain 3-hydroxy fatty acids, to Devosia riboflavina gen. nov., sp. nov., nom. rev. Int J Syst Bacteriol 46, 16-22.

Ryu, S. H., Chung, B. S., Le, N. T., Jang, H. H., Yun, P. Y., Park, W. \& Jeon, C. O. (2008). Devosia geojensis sp. nov., isolated from dieselcontaminated soil in Korea. Int J Syst Evol Microbiol 58, 633-636.

Saitou, N. \& Nei, M. (1987). The neighbor-joining method: a new method for reconstructing phylogenetic trees. Mol Biol Evol 4, 406425.

Schlesner, H. (2005). Genus X. Filomicrobium Schlesner 1988, $220^{\mathrm{VP}}$ (Effective publication: Schlesner 1987, 65). In Bergey's Manual of Systematic Bacteriology, 2nd edn, vol. 2C, pp. 518-520. Edited by D. J. Brenner, N. R. Krieg, J. T. Staley \& G. M. Garrity. New York: Springer.

Stackebrandt, E. \& Goebel, B. M. (1994). Taxonomic note: a place for DNA-DNA reassociation and $16 \mathrm{~S}$ rRNA sequence analysis in the present species definition in bacteriology. Int J Syst Bacteriol 44, 846849.

Tamura, K., Dudley, J., Nei, M. \& Kumar, S. (2007). MEGA4: molecular evolutionary genetics analysis (MEGA) software version 4.0. Mol Biol Evol 24, 1596-1599.

Thompson, J. D., Higgins, D. G. \& Gibson, T. J. (1994). ClusTAL W: improving the sensitivity of progressive multiple sequence alignment through sequence weighting, position-specific gap penalties and weight matrix choice. Nucleic Acids Res 22, 4673-4680.

Truu, J., Kärme, L., Talpsep, E., Heinaru, E., Vedler, E. \& Heinaru, A. (2003). Phytoremediation of solid oil shale waste from the chemical industry. Acta Biotechnol 23, 301-307.

Xu, X.-W., Wu, Y.-H., Zhou, Z., Wang, C.-S., Zhou, Y.-G., Zhang, H.-B., Wang, Y. \& Wu, M. (2007). Halomonas saccharevitans sp. nov., Halomonas arcis sp. nov. and Halomonas subterranea sp. nov., halophilic bacteria isolated from hypersaline environments of China. Int J Syst Evol Microbiol 57, 1619-1624.

Xu, X.-W., Wu, Y.-H., Wang, C.-S., Yang, J.-Y., Oren, A. \& Wu, M. (2008). Marinobacter pelagius sp. nov., a moderately halophilic bacterium. Int J Syst Evol Microbiol 58, 637-640.

Xu, H.-Y., Chen, L.-P., Fu, S.-Z., Fan, H.-X., Zhou, Y.-G., Liu, S.-J. \& Liu, Z.-P. (2009). Zhangella mobilis gen. nov., sp. nov., a new member of the family Hyphomicrobiaceae isolated from coastal seawater. Int $J$ Syst Evol Microbiol 59, 2297-2301. 